\title{
ESSENSI GANTI RUGI IMMATERIEL DALAM PERBUATAN MELANGGAR HUKUM MENURUT PUTUSAN HAKIM PERDATA INONESIA
}

\author{
Markus Suryoutomo*
}

\begin{abstract}
Legal findings by judges in interpreting the meaning of the text of the Act can function to realize and provide protection for the community of justice seekers, National legislation and its conclusions in the form of court decisions are reported to be open to various studies and deconstructive criticism that carried out through various social movements that care about the law, so that national law can function as one of the forces to mobilize the lives of new Indonesian people who are able to act responsively for the public interest. From this definition the obligation of the Judge to uphold justice comes from its authority, namely the Judicial Discretion policy. In the event that the judge grants Maternity compensation to the Law Breaking Lawsuits, insofar as it has fulfilled the Elements of Article 1365 of the Civil Code, which brings the legal consequences the judge can grant Immaterial compensation based on found evidence that can be justified. Granted Losses Immaterial is based on the legal accountability of the perpetrator of the victim. The obligation of the Judge to enforce justice comes from its authority, namely the judge's policy (Judicial Discretion), as a moral principle of the Foundation of Law.
\end{abstract}

Keywords: Onrechmatige Daad, Immateriële Schade Vergoeding, Ratio Decidendi.

\section{PENDAHULUAN}

Negara Kesatuan Republik Indonesia adalah negara hukum yang menjamin supremasi hukum, yang terefleksi dalam penegakan hukum (enforcement of Law) dan keadilan (equality) berdasaran Undang-Undang Dasar 1945. Upaya keras dalam membuat aturan, dilakukan dengan cara:

1. Mengadakan Penataan ulang Lembaga kenegara;

2. Meningkatkan kualifikasi aparat negara; dan

3. Penataan ulang perundang-undangan yang berlaku. ${ }^{1}$

* Markus Suryoutomo adalah Pengajar di Fakultas Hukum UNTAG Semarang, Bidang Kajian Hukum Perdata, dapat di hubungi melalui email: msu_atlaw@yahoo.co.id

1 Titik Triwulan Tutik, Hukum Perdata Dalam System Hukum Nasional, cet-4, Jakarta: Kencana Prenadamedia, Jakarta. 2014, Hlm. 1
Tanpa adanya aturan akan terjadi ketidak-teraturan (disorder/chaos), untuk itu dibutuhkan adanya aturan sebagai pedoman berperilaku, pedoman ini dinamakan hukum. Soediman Kartohardiprodjo mengatakan bahwa "suatu unsur pokok hukum ialah, bahwa hukum itu adalah sesuatu yang berkenaan dengan manusia". Sementara Menurut Jaap Hage hukum itu sebagai teknik untuk mengendalikan perilaku (recht als techniek om gedrag te sturen), namun demikian tidak selalu dipikirkan mengenai peraturan perundang-undangan (hukum tertulis/ geschreven recht) di atas segalanya (bij recht als techniek om gedrag te sturen hoeven we dus niet per se te denken). ${ }^{3}$

2 Soediman Kartohardiprodjo, Pengantar Hukum Indonesia 1 Hukum Perdata, Cet-11, Jakarta : Ghalia Indonesia, 1987, hlm. 1.

3 Jaap C. Hage, De Wereld van het Recht, dalam Recht, vaardig, en zeker, Een Inleiding in het recht, vijde druk, onder redactie van Jaap C. Hage, Den Haag : Boom Juridische Uitgevers, 2010, hlm. 30. 
Hal ini dapat dipahami, mengingat terdapat pula hukum tidak tertulis (ongeschreven recht).

Indonesia negara hukum (rechtsstaat), ditegaskan dalam Pasal 1 ayat (3) UUD 1945. Sebagai negara hukum arahnya pada dua tradisi sistem hukum, antara lain Civil Law System (European Continental System) dan Common Law System (Anglo-Saxon Law System). ${ }^{4}$

Di dalam Hukum keperdataan Indonesia terdapat pengaruh yang sangat kuat dari Kolonial Belanda yang disebabkan lintasan sejarah, sekalipun demikian varian penerapannya berbeda atas peristiwa hukum, mengingat masih ada hukum Islam dan Hukum Adat. ${ }^{5}$

Berlakunya hukum perdata ada yang bersifat memaksa (dwingend), dan ada pula bersifat sukarela, bersifat memaksa artinya kewajiban hukum harus dilaksana kan, baik dengan berbuat atau tidak berbuat. $^{6}$

Atas dasar cara penyusunan KUHPerdata dalam Buku III secara khusus diatur sebagai bentuk khusus perikatan. Maka pada umumnya para sarjana memberikan perikatan seperti yang dimaksud dalam buku III KUHPerdata sebagai: "Perikatan adalah hubungan hukum dalam lapangan harta kekayaan, dimana disatu pihak ada hak dan di lain pihak ada kewajiban".?

Sumber pokok dari perikatan adalah Perjanjian dan Undang-Undang, dan sumber dari Undang-Undang dapat dibagi lagi menjadi Undang-Undang dan perbuatan mausia dan Undang-Undang

4 Peter Mahmud Marzuki,2011, An Introduction to Indonesian Law, Malang : Setara Press, hlm. 26.

5 Herman J. A. C. Arens, ADAT LAW IN INDONESIA. By B. ter Haar. New York: Institute of Pacific lR elations. 1948., 3 U. Miami L. Rev.657,(1949), hlm. 658.

6 Abdulkadir Muhammad Loc. Cit hlm 18

7 R. Subekti,1983 Pokok-pokok Hukum Perdata, PT, Intermasa Jakarta, hlm. 122-123 melulu, sedangkan sumber dari UndangUndang dan Perikatan manusia dibagi lagi menjadi perbuatan yag menurut hukum dan Perbuatan yang melawan hukum. ${ }^{8}$

Pengaturan perbuatan melanggar hukum dalam KUHPerdata hanya 15 Pasal, yaitu pasal 1365-1380 KUPerdata, tetapi dalam kenyataannya menunjukkan bahwa jumlah perkara di tingkat Kasasi sebanyak: (16178) terdiri dari Perceraian (309) Tanah (9458), Pembagian Harta (92) Perjanjian (1143) Wanprestasi (1581). Perbuatan Melawan Hukum (7352) Permohonan (11) Waris (1752). Gugatan perdata di Pengadilan didominasi oleh gugatan perbuatan melanggar hukum disamping gugatan mengenai sengketa yang lainnya. Perbuatan melanggar hukum dapat ditujukan kepada harta kekayaan orang lain dan dapat ditujukan kepada diri pribadi orang lain, perbuatan mana mengakibatkan kerugian bagi orang lain itu. Dalam hukum Anglo Saxon, perbuatan melanggar hukum diistilahkan dengan kata "tort". ${ }^{10}$

Perbuatan Melanggar Hukum (onrechtmatige daad), meburut pasal 1365 KUHPerdata menentukan bahwa: Tiap perbuatan melanggar hukum yang menimbulkan kerugian pada orang lain, mewajibkan orang yang bersalah menimbulkan kerugian itu, mengganti kerugian tersebut. Suatu perbuatan dikatakan merupakan suatu perbuatan melanggar hukum apabila memenuhi unsur-unsur:

1. Adanya suatu Perbuatan;

2. Perbuatan tersebut melanggar hukum;

3. Adanya kesalahan dari pihak pelaku;

4. Adanya kerugian bagi korban dan;

5. Adanya hubungan kausal antara

8 Purwahid Patrik, 1994, Dasar-Dasar Hukum Prikatan, Mandar Maju Bandung. hlm 9

9 Direktori Putusan Mahkamah Agung bidang Perdata Umum diunduh tanggal 20 September 2018

10 Munir Fuady,Perbuatan Melawan Hukum Pendekatan Kontemporer, Citra Aditya Bakti, Bandung, $2013 \mathrm{hlm} .33$ 
perbuatan dengan kerugian. ${ }^{11}$

Salah satu saja dari unsur-unsur ini tidak terpenuhi, maka perbuatan itu tidak dapat dikatakan perbuatan melanggar hukum. ${ }^{12}$ Kata "perbuatan" meliputi perbuatan positif, yang dalam bahasa aslinya bahasa Belanda "daad" (pasal 1365 KUHPerdata) dan perbuatan negatif, yang dalam bahasa aslinya bahasa Belanda "natigheid" (kelalaian) atau "onvoorzigtigheid" (kurang hati-hati) seperti ditentukan dalam pasal 1366 KUHPerdata. Dengan demikian, pasal 1365 itu untuk orang yang betul-betul berbuat, sedangkan pasal 1366 itu untuk orang yang tidak berbuat. Pelanggaran dua pasal ini mempunyai akibat hukum yang sama, yaitu mengganti kerugian.

Perumusan perbuatan positif dalam pasal 1365 KUHPerdata dan perbuatan negatif dalam pasal 1366 KUHPerdata hanya mempunyai arti sebelum ada putusan Mahkamah Agung Belanda 31 Januari 1919, karena pada waktu itu pengertian "melanggar hukum" masih sempit. Setelah ada putusan Mahkamah Agung itu, Pengertian Melanggar hukum pada awalnya mengandung pengertian yang sempit sebagai pengaruh dari ajaran legisme. Pengertian yang dianut adalah bahwa perbuatan Melanggar hukum merupakan perbuatan yang bertentangan dengan hak dan kewajiban hukum menurut undangundang. Dengan kata lain bahwa perbuatan melanggar hukum (onrechtmatige daad) sama dengan perbuatan melanggar undangundang (onwetmatigedaad).

11 R. Subekti dan Tjitrosudibio, 2003 Kitab Undang-Undang Hukum Perdata, Pradnya Paramita,Jakarta: hlm. 288.

12 Ibid, Munir Fuady Menyatakan: Bahwa agar seseorang dapat dinyatakan telah melakukan perbuatan melanggar hukum sehingga dapat dikenakan pasal 1365 KUHPerdata, maka unsurunsur dari pasal1365 tersebut haruslah terpenuhi seluruhnya, jika ada salah satu unsur yang tidak terpenuhi/tidak dapat dibuktikan oleh pihak penggugat, maka oleh hukum dianggap tidak terjadi perbuatan yang melawan hukum tersebut. Hlm. 167-168
Pengaturan dan pelaksanaan dalam gugatan perbuatan melanggar hukum di Indonesia dalam Kitab Undang-Undang Hukum Perdata mengatur tentang ganti rugi dari kerugian yang bersifat Material (berwujud) yang dapat dinilai dengan uang, dan tidak mengatur ganti rugi dari kerugian yang bersifat Immateriel, ${ }^{13}$ tidak berwujud (moral, ideal). Yurisprudensi ${ }^{14}$ menyetujui diberikannya ganti rugi terhadap kerugian Immateriel, Perbuatan melanggar hukum di Indonesia secara normatif selalu merujuk pada ketentuan Pasal 1365 KUHPerdata. Perumusan norma pasal 1365 KUHPerdata lebih merupakan struktur norma dari pada substansi ketentuan hukum. Oleh karenanya substansi kerugian Immateriel mendasarkan ketentuan pasal 1365 KUHPerdata memerlukan Interpretasi atau penafsisar tersendiri di luar KUHPerdata.

Tanggung jawab perbuatan melanggar hukum hadir untuk melindungi hak-hak seseorang. Hukum dalam perbuatan Melanggar hukum menggariskan hak-hak dan kewajiban-kewajiban saat seseorang melakukan perbuatan baik kesalahan atau kelalaian atau melukai orang lain dan perbuatan tersebut menimbulkan kerugian bagi orang lain.

Perbuatan Melanggar hukum di Indonesia secara normatif selalu merujuk pada ketentuan Pasal 1365 KUHPerdata. Rumusan norma dalam pasal ini unik, tidak seperti ketentuan-ketentuan pasal lainnya. Perumusan norma pasal 1365 KUHPerdata lebih merupakan struktur norma dari pada substansi ketentuan hukum yang sudah lengkap, oleh karenanya substansi ketentuan pasal 1365 KUHPerdata senantiasa memerlukan materialisasi di luar KUHPerdata.

Bagaimana aturan tentang perbuatan melanggar hukum di Indonesia,

13 Munir Fuadi Loc.Cit. 2013 Hlm. 141-143

14 Yurisprudensi berasal dari "iuris"prudential (latin)Jurisprudentie (Belanda) Jurisprudence (Perancis) yang berarti Ilmu Hukum (Black's Law Dictionary, edisi nineth, 2004). 
atas perkara kerugian materiil dan Immateriel yang dimohonkan oleh penggugat jika Undang-undang maupun hukum adat tidak mengatur secara jelas. Pengadilan harus tetap memutus kasus tersebut. Karena setiap orang berhak untuk mengajukan permohonan ke pengadilan mengenai apa yang diatur atau tidak diatur oleh undang-undang, berdasarkan prinsip hukum umum, seseorang mempunyai hak untuk mendapatkan nasihat hukum mengenai masalah yang timbul dari kehidupan sehari- hari. ${ }^{15}$

Pengaturan dan pelaksanaan dalam gugatan perbuatan melanggar hukum di Indonesiadalam Kitab Undang-Undang Hukum Perdata mengatur tentang ganti rugi dari kerugian yang bersifat Materiel (berwujud) yang dapat dinilai dengan uang, dan tidak mengatur ganti rugi dari kerugian yang bersifat Immateriel, ${ }^{16}$ tidak berwujud (moral, ideal). Yurisprudensi ${ }^{17}$ menyetujui diberikannya ganti rugi terhadapkerugian Immateriel, Perbuatan melanggar hukum di Indonesia secara normatif selalu merujuk pada ketentuan Pasal 1365 KUHPerdata. Perumusan norma pasal 1365 KUHPerdata lebih merupakan struktur norma dari pada substansi ketentuan hukum. Oleh karenanya substansi kerugian Immateriel mendasarkan ketentuan pasal 1365 KUHPerdata memerlukan perumusan norma di luar KUHPerdata. pembahasan tentang Kriteria Ganti Rugi Immateriel dalam Perbuatan Melanggar Hukum Berdasarkan Putusan Hakim Perdata Indonesia, adalah suatu upaya hukum dalam pemenuhan ganti rugi yang wujudnya kerugian Immateriel, jika ganti rugi materiil dengan mudah dibuktikan, sementara ganti rugi Immaterril secara hukum tidak diatur, namun demikian dari

15 Peter Mahmud Marzuki, Pengantar Ilmu Hukum, Jakarta, kencana Prenada Media Group, 2012,Hlm. 27

16 Munir Fuady, Perbuatan Melawan Hukum Pendekatan Kontemporer, Citra Aditya Bakti, Bandung, 2013 hlm. 141-143

17 Black 's Law Dictionary edisi nineth, 2014 berbagai Yurisprudensi putusan hakim mengabulkan Gugatan Immateriel. Di dalam mengkaji mengenai rasio desidendi atas putusan hakim tentang dikabulnya ganti rugi Immateriel. Pengaturan dan pelaksanaan dalam gugatan perbuatan melanggar hukum di Indonesiadalam Kitab Undang-Undang Hukum Perdata mengatur tentang ganti rugi dari kerugian yang bersifat Materiel (berwujud) yang dapat dinilai dengan uang, dan tidak mengatur ganti rugi dari kerugian yang bersifat Immateriel, ${ }^{18}$ tidak berwujud (moral, ideal). Yurisprudensi ${ }^{19}$

menyetujui diberikannya ganti rugi terhadapkerugian Immateriel, Perbuatan melanggar hukum di Indonesia secara normatif selalu merujuk pada ketentuan Pasal 1365 KUHPerdata. Perumusan norma pasal 1365 KUHPerdata lebih merupakan struktur norma dari pada substansi ketentuan hukum. Oleh karenanya substansi kerugian Immateriel mendasar kan ketentuan pasal 1365 KUHPerdata memerlukan perumusan norma di luar KUHPerdata. Dari uraian tersebut diatas maka dalam penelitian ini akan dirumuskan suatu masalah sebagai fokus studi tentang norma pemberian ganti rugi Immateriel.

Pembahasan tentang Kriteria Ganti Rugi Immateriel dalam Perbuatan Melanggar Hukum, adalah suatu upaya hukum dalam pemenuhan ganti rugi yang wujudnya kerugian Immateriel, jika ganti rugi materiil dengan mudah dibuktikan, sementara ganti rugi Immaterril secara hukum tidak diatur,namun demikian dari berbagai Yurisprudensi putusan hakim mengabulkan Gugatan Immateriel. Di kajian mengenai rasio desidendi atas putusan hakim tentang dikabulnya ganti rugi Immateriel.

Dari uraian yang mendasari Permasalah terbut diatas dapat dirumuskan suatu Permasalahan tentang "Bagaimana

18 R. Subekti dan Tjitrosudibyo, 2003, KUHPerdata, Lo. Cit. Hlm. 288

19 Sudikno Mertokusumo, 2003 Lo. Cit. Hlm. 67 
essensi Putusan Hakim Perdata Mengabul kan Gugatan Ganti Rugi Immateriel dalam Perbuatan Melanggar Hukum";

\section{PEMBAHASAN}

Persoalan utama yang dihadapi lembaga peradilan adalah cara pandang hakim terhadap hukum yang normative procedural dalam melakukan konkritisasi hukum. Hakim hanya menangkap apa yang disebut "keadilan hukum (legal Jastice)", namun gagal menangkap keadilan masyarakat (Social Justice), Hakim telah meninggalkan pertimbangan hukum yang dalam putusannya. Akibatnya kinerja pengadilan masih menunjukkan lebih kental "formalisme procedural" dari pada "rasa keadilan procedural." Yang lebih ada kedekatan pada"rasa keadilan warga masyarakat"

Berlakunya hukum perdata ada yang bersifat memaksa ( $d$ wingend), dan ada pula bersifat sukarela, bersifat memaksa artinya kewajiban hukum harus dilaksana kan, baik dengan berbuat atau tidak berbuat. $^{20}$

Atas dasar cara penyusunan KUHPerdata dalam Buku III secara khusus diatur sebagai bentuk khusus perikatan. Maka pada umumnya para sarjana memberikan perikatan seperti yang dimaksud dalam buku III KUHPerdata sebagai: "perikatan adalah hubungan hukum dalam lapangan harta kekayaan, dimana disatu pihak ada hak dan di lain pihak ada kewajiban". ${ }^{21}$

Sumber pokok dari perikatan adalah Perjanjian dan Undang-Undang, dan sumber dari Undang-Undang dapat dibagi lagi menjadi Undang-Undang dan perbuatan mausia dan Undang-Undang melulu, sedangkan sumber dari UndangUndang dan Perikatan manusia dibagi lagi menjadi perbuatan yag menurut hukum dan

20 Abdulkadir Muhammad Loc. Cit hlm 18

21 R. Subekti,1983 Pokok-pokok Hukum Perdata, PT, Intermasa Jakarta, hlm. 122-123
Perbuatan yang melawan hukum. ${ }^{22}$

menjadi perbuatan yag menurut hukum dan Perbuatan yang melawan hukum.

\section{Unsur Perbuatan Melanggar Hukum}

Dalam hal subyek hukum melakukan perbuatan melawan hukum, maka subyek hukum yang bersangkutan dapat dituntut membayar ganti kerugian, sebagaimana yang diatur dalampasl 1365 KUHPerdata. Timbulnya ganti rugi ini disebabkan subyek hukum yang bersangkutan melakuhan kesalahan terhadap subyek hukum lainnya. Kesalahannya berupa subyek hukum melakukan perbuatan melawan hukum. Menurut H.R, 1919 yang diartikan dengan perbutan melawan hukum adalah berbuat atau tidak berbuat yang:

1. Melanggar hak orang lain, yang dimaksud dengan hak orang lain, bukan semua hak tetapi hanya hak-hak pribadi, seperti integritas tubuh kebebasan,kehormatan dan lain-lain. Dan hak hak absolut, seperti hak kebendaan,oktroi nama perniagaan, hak cipta dan lain;

2. Bertentangan dengan kewajiban hukum pelaku kewajiban hukum hanya kewajiban yang dirumuskan dalam aturan undang-undang;

3. Bertentangan dengan kesusilaan, artinya perbuatan yang dilakukan oleh seseorang itu bertentangan dengan sopan santun yang tidak tertulis yang tumbuh dan berkembang dalam masyarakat; dan

4. Bertentangan dengan kecermatan yang harus diindahkan dalam masyarakat. Aturan tentang kecermatan terdiri dari atas dua kelompok, yaitu: 1). Aturan aturan yang mencegah orang lain terjerumus dalam bahaya, dan 2). Aturan-aturan yang melarang merugikan orang lain ketika hendak

22 Purwahid Patrik, 1994, Dasar-Dasar Hukum Prikatan, Mandar Maju Bandung. hlm 9 
menyelenggarakan kepentingan sendiri. ${ }^{23}$

Berdasarkan Pasal 1365 KUHPerdata, suatu perbuatan dikatakan merupakan suatu perbuatan melawan hukum apabila memenuhi unsur-unsur :

1. Perbuatan;

2. Perbuatan tersebut melawan hukum;

3. Ada kesalahan;

4. Ada kerugian dan;

5. Terdapat hubungan kausal antara perbuatan dengan kerugian.

Dari lima unsur tersebut diatas akan diuraikan satu persatu: ${ }^{24}$

\section{Perbuatan}

Unsur perbuatan sebagai unsur yang pertama dapat digolongkan dalam dua bagian yaitu perbuatan yang merupakan kesengajaan (dilakukan secara aktif) dan perbuatan yang merupakan kelalaian (pasif atau tidak berniat melakukannya).

\section{Melawan hukum}

Perbuatan pada unsur pertama dikatakan memenuhi unsur kedua yaitu melangar hukum apabila memenuhi ketentuan sebagai berikut:

a. Bertentangan dengan hak subyektif oranglain

Melanggar hak subyektif orang lain berarti melanggar wewenang khusus yang diberikan oleh hukum kepada seseorang. Sifat hakikat dari hak subyektif wewenang khusus yang diberikan oleh hukum kepada seseorang yang memperolehnya demi kepentingan.

Karakteristik untuk hak subyektif seseorang adalah :

23 Nieuwenhuis,1985, Pokok pokok Hukum Perikatan, diterjemahkan Djasadin siragih (Surabaya Universitas Airlangga, hlm. 118

24 Rosa Agustina, 2012, Hukum Perikatan, Law Of Obligation, Pustaka Larasan, Den Pasar. Hlm. 811
1). Kepentingan yang mempunyai nilai tinggi terhadap yang bersangkutan.

2). Pengakuan langsung terhadap kewenangan yang bersangkut an oleh suatu peraturan perundang-undangan.

3). Suatu posisi pembuktian yang kuat dalam suatu perkara yang mungkin timbul.

Hak subyektif dalam masyarakat dikenal sebagai :

a). Hak kebendaan yang absolut, misalnya hak milik;

b). Hak-hak pribadi, seperti hak untuk mempunyai integritas terhadap jiwa dan kehidupan, kebebasan pribadi, kehormatan dan nama baik.

c). Hak-hak istimewa, misal nya hak untuk menempati rumah oleh penyewa rumah

b. Bertentangan dengan kewajiban hukum si pelaku

Menurut pandangan yang berlaku saat ini, hukum diartikan sebagai suatu keseluruhan yang terdiri dari norma-norma yang tertulis maupun yang tidak tertulis.

Yang dimaksud dengan suatu tindakan atau kelalaian yang bertentangan dengan kewajiban hukum sipelaku adalah suatu tingkah laku yang bertentangan dengan suatu ketentuan undangundang. Yang dimaksud dengan undang-undang di sini adalah semua peraturan yang sah yang dikeluarkan oleh instansi yang berwenang dan mempunyai daya ikat keluar.

c. Bertentangan dengan kesusilaan Kaidah kesusilaan diartikan sebagai norma-norma sosial dalam masyarakat, sepanjang norma tersebut diterima oleh anggota masyarakat sebagai/dalam bentuk 
peraturan-peraturan hukum yang tidak tertulis. Sebagai pertimbangan ialah kasus antara Lindenbaum vs. Cohen dimana perbuatan Cohen dinilai bertentangan dengan tata susila, ketika ia membuku karyawan Lindenbaum untuk membocorkan rahasia perusahaan nya.

d. Bertentangan dengan kepatutan, ketelitiandan kehati-hatian (patiha) Dalam pengertian ini manusia harus mempunyai tenggang rasa dengan lingkungannya dan sesama manusia, sehingga tidak hanya mementingkan kepentingan pribadi tetapi juga kepenting an orang lain sehingga dalam bertindak haruslah sesuai dengan kepatutan, ketelitian dan kehati-hatian yang berlaku dalam masyarakat.

Perbuatan yang termasuk dalam kategori bertentangan dengan kepatutan, yaitu: ${ }^{25}$

1). Perbuatan yang merugikan orang lain tanpa kepentingan yang layak:

2). Perbuatan yang tidak berguna yang menimbulkan bahaya bagi orang lain berdasarkan pemikiran yang normal perlu diperhatikan. Walaupun ketentuan mengenai patihan ini didasarkan pada kaidah tidak tertulis, namun dalam pengujiannya tetaplah merupakan pengujian norma-norma yuridis di mana peraturan-peraturan tidak tertulis tersebut (norma) dihubungkan dengan karakter dari norma-norma hukum.

\section{Kesalahan}

Unsur kesalahan pada suatu perbuatan sebenarnya tidak berbeda jauh dengan unsur melawan hukum, unsur ini menekankan pada kombinasi antara kedua unsur di atas dimana perbuatan (yang meliputi kesengajaan atau kelalaian) yang

25 R. Setiawan, 1979,Pokok-pokok Hukum Perikatan, Bandung: Binacipta, hlm. 82-83. memenuhi unsur-unsur melawan hukum. Unsur kesalahan dipakai untuk menyatakan bahwa seseorang dinyatakan bertanggung jawab untuk akibat yang merugikan yang terjadi karena perbuatannya yang salah.

\section{Kerugian}

Pasal 1365 KUHPerdata menentu kan kewajiban pelaku perbuatan melawan hukum untuk membayar ganti rugi. Namun tidak ada pengaturan lebih lanjut mengenai ganti kerugian tersebut. Pasal 1371 ayat (2) KUHPerdata memberikan sedikit pedoman untuk itu dengan menyebutkan : "Juga penggantian kerugian ini dinilai menurut kedudukan dan kemampuan kedua belah pihak dan menurut keadaan". Pedoman selanjutnya dapat ditemukan pada Pasal 1372 ayat (2) KUH Perdata yang menyatakan : "Dalam menilai satu dan lain, Hakim harus memperhatikan berat ringannya penghinaan, begitu pula pangkat, kedudukan dan kemampuan kedua belah pihak, dan pada keadaan".

Dalam hukum perdata dipersoalkan apakahada perbedaan pengertian antara kerugian sebagai akibat suatu perbuatan melawan hukum disatu pihak dan kerugian sebagai akibat dari tidak terlaksananya suatu perjanjian di lain pihak. Pasal 1365 KUHPerdata menamakan kerugian akibat perbuatan melawan hukum sebagai "scade" (rugi) saja, sedangkan kerugian akibat wanprestasi oleh Pasal 1246 KUHPerdata dinamakan "Kosten, scaden en interessen" (biaya, kerugian dan bunga).

Penentuan ganti kerugian berdasar kan pasal 1365 KUHPerdata menunjukkan segi-segi persamaan dengan penentuan ganti kerugian karena wanprestasi, tetapi juga dalam beberapa hal berbeda. Dalam undang-undang tidak diatur tentang ganti kerugian yang harus dibayar karena perbuatan melawan hukum, sedang pasal 1243 KUH Perdata memuat ketentuan tentang ganti kerugian yang harus dibayar karena wanprestasi. Untuk penentuan ganti 
kerugian karena perbuatan melawan hukum dapat diterapkan ketentuan-ketentuan yang sama dengan ketentuan tentang ganti kerugian karena wanprestasi. Mengenai kerugian kekayaan (vermogenschade), penggantian pada umumnya terdiri dari penggantian atas kerugian yang diderita dan juga berupa keuntungan yang sekiranya dapat diharapkan diterimanya (gederf dewinst). Sehubungan dengan hal tersebut tidaklah semudah diperkirakan untuk menetapkan besarnya jumlah ganti kerugian tersebut. Sebagai ketentuan umum kiranya dapat digunakan kenyataan bahwa maksud dari kewajiban memberikan ganti kerugian adalah untuk membawa sipenderita sedapat mungkin pada keadaan sekiranya tidak terjadi perbuatan melawan hukum.

\section{Adanya hubungan kausal antara perbuatan dan kerugian}

Unsur terakhir yang tidak kalah penting adalah adanya hubungan kausal antara perbuatan dengan kerugian yang diderita. Pada unsur ini kerugian yang diderita oleh korban haruslah benar-benar sebagai akibat dari perbuatan yang dilakukan oleh pelaku bukan oleh akibat perbuatan lain.

Ada dua ajaran yang berkaitan dengan hubungan kausal, yaitu : $:^{26}$

a. Teori Conditio Sine Qua Non (Van Buri) Inti dari ajaran ini yaitu : tiap-tiap masalah, yang merupakan syarat untuk timbulnya suatu akibat, adalah sebab dari akibat.

b. Teori Adaequate Veroorzaking (Von Kries)

Teori ini mengajarkan bahwa perbuatan yang harus dianggap sebagai sebab dari akibat yang timbul adalah perbuatan yang seimbang dengan akibat. Dasar untuk menentukan "perbuatan yang seimbang" adalah perhitungan yang layak, yaitu menurut akal sehat patut

26 Rosa Agustina, 2012, Loc Cit. Hlm. 11 dapat diduga bahwa perbuatan tersebut dapat menimbulkan akibat tertentu.

Dalam gugatan perbuatan melanggar hukum sebagaimana diuraikan di atas dapat meminta kerugian materiil dan Immateriel, kerugian materiil dapat dibuktikan atau already done sementara Kerugian Immateriel terbatas pada aspek kematian, luka berat dan penghinaan, seperti muatan di dalam Pasal 1371, 1372 dan 1373 KUHPerdata. Diluar ketentuan aspek kematian, luka berat dan penghinaan, terdapat perluasan makna yang tidak diatur dalam pasal 1371, 1372 dan 1373 KUHPerdata dimana dalam putusannya hakim mengabulkan kerugian Immateriel, seperti yang dapat dikaji dalam penelitian ini, antara lain:

1. Putusan Pengadilan Negeri Semarang Nomor 304/Pdt/2011/PN.Smg. yang dikuatkan oleh Putusan Tingkat Banding Nomor 254/Pdt/2012/ PT.SMG JoPutusan Kasasi Nomor 820 K/Pdt/2013 Jo Putusan PK Nomor 632 $\mathrm{PK} / \mathrm{Pdt} / 2014$. Sengketa ini terkait hilangnya bagasi penumpang Lion Air yang telah dipercayakan sepenuhnya kepada pihak maskapai dari Medan ke Semarang dengan nilai kerugian materiil sebesar Rp19.115.000 dan tuntutan kerugian Immateriel sebesar 100 (seratus) kali lipat dari total kerugian materiil yakni sebesar Rp1.911.500.000,00 Pengadilan Negeri Semarang mengabulkan gugatan penggugat dengan menyatakan Tergugat telah melakukan perbuatan melanggar hukum, Putusan hakim mengabulkan kerugian materiil sebesar Rp19.115.000 dan juga mengabulkan kerugian Immateriel sebesar Rp19.115.000.

2. Putusan Pengadilan Negeri Tangerang Nomor305/Pdt.G/2009/PN.Tng yang dikuatkan oleh Putusan Tingkat Banding Nomor 54/Pdt/2010/PT.BTN Jo Putusan Kasasi Nomor 1391 K/Pdt/2011 Jo Putusan PK Nomor 334 
PK/Pdt/2014. dalam Putusan ini antara Hasto Boedi Wibowo melawan PT Indonesia Air Asia atas perbuatan Melanggar hukum, pembatalan penerbangan secara sepihak melalui Short Message Service(SMS). Padahal Penggugat akan menjadi pembicara tunggal Workshop Program Studi Desain Komunikasi sehingga Penggugat sangat kecewa dengan pelayanan yang diberikan oleh Tergugat. Secara subjektif kemudian majelis hakim mempertimbangkan kepantasan dan keadilan dengan mengabulkan kerugian Immateriel sebesar Rp50.000.000.

Uraian di atas memiliki persamaan kaidah Putusan Nomor 305/Pdt.G/2009/ PN.Tng dengan Putusan Nomor 304/Pdt/2011/ PN.Smg bahwa perbuatan Melanggar hukum akibat kekecewaan pelayanan jasa penerbangan termasuk hal yang dapat dikabulkan tuntutan kerugian Immateriel. Para Hakim di dalam perkara ini menerobos batasan ruang lingkup di dalam Putusan MA No. 650/PK/Pdt/1994 dengan pendeketan judicial activism ${ }^{27}$ atas rasa keadilan yang hidup dan berkembang an di masyarakat serta kerugian Immateriel yang wajar.

Berdasarkan putusan tersebut terlihat adanya keaktifan dan keberanian dari para hakim untuk melepaskan diri dari ketentuan Perundang-Undangan (Justicial Activism) ${ }^{28}$

Pertimbangan tersebut menjadi arahan bagi hakim dalam memutuskan suatu kasus yang bersangkutan karena adanya perkambangan baruatau berbeda dengan putusan-putusan sebelumnya dalam kasus yang sama.

27 Lihat ketentuan Pasal 5 ayat 1 Undang-undang Nonor 48 Tahun 2009 tentang Kekuatan Kehakiman

28 Pengertian Judicial Activism adalah suatu filosofi dari pembuat putusan peradilan dimana para hakim mendasarkan pertimbanganpertimbangan putusan, antara lain pada pandangan hakim terhadap perkembangan baru atau kebijakan public yang berkembang.
Disamping itu Terhadap Putusan yang menolak Gugatan Immateriel Putusan perkara Perdata antara : PT. Natura Herbalindo, berkedudukan di J1. Sunter Indah No.14 KG2/16, Jakarta; Pemohon Kasasi dahulu Penggugat/Terbanding; $m$ e 1 a w a n : PT. Air Mancur, berkedudukan di J1. Raya Solo-Sragen Km.7, Jaten Karanganyar ; Termohon Kasasi dahulu Tergugat/Pembanding ; Menimbang, bahwa pertimbangan hukum serta putusan Putusan Mahkamah Agung No : 811 K/Pdt/2006 Tanggal 21 September 2006 Jo No.363/Pdt/2004/PT.Smg. Tanggal 23 Februari 2005 Jo No.01/Pdt.G/2004/PN. Kray Tanggal 07 Juli 2004, yang mengabul kan kerugian Materiel tetapi menolak kerugian immateriil karena atas kerugian Immateriel Penggugat tidak merinci secara jelas, pada bagan dibawah ini disajikan Putusan yang mengabulkan maupun tidak mengabulkan kerugian Materiel maupun Immateriel: Prinsip yang digunakan dalam kedua pasal tersebut adalah Leability Based On Fault dengan beban pembuktianyang memberatkan penderita.Ia baru akan memperoleh ganti kerugian apabila ia berhasil membuktikan adanya unsur kesalahan pada pihak Tergugat. Kesalahan di sinimerupakan unsur yang menentukan pertanggung-jawaban, yang berarti bila tidak terbukti adanya kesalahan, tidak ada kewajiban memberi ganti kerugian.

Didalam pandangan tersebut diatas, teori tentang tanggung jawab hukum yang dipakai adalah teori Liability based on fauld. Dalam kaitan dengan pembuktian perlu dikemukakan, bahwa barang siapa mengajukan peristiwa-peristiwa di atas akan mendasarkan sesuatu hak, diwajibkan membuktikan peristiwa-peristiwa mendasarkan suatu hak, diwajibkan membuktikan peristiwa-peristiwa itu, sebaliknya barang-siapa mengajukan peristiwa-peristiwa guna pertahanan hak orang lain, diwajibkan membuktikan peristiwa-peristiwa itu. ${ }^{29}$ 
Pasal 10 (1) Dalam UndangUndang Republik Indonesia Nomor 48 Tahun 2009 Tentang Kekuasaan Kehakiman: Pengadilan dilarang menolak untuk memeriksa, mengadili, dan memutus suatu perkara yang diajukan dengan dalih bahwa hukum tidak ada atau kurang jelas, (kekosongan hukum atau hukumnya tidak jelas) melainkan wajib untuk memeriksa dan mengadilinya.adalah nilai-nilai hukum dan rasa keadilan yang hidup dalam masyarakat. Dari ketentuan UndangUndang memberikan ruang bagi eksistensi hakim sebagai tonggak dalam penemuan hukum diberikan ruang dan kewenangan untuk melakukan penemuan hukum berdasarkan pada kewenangannya yang diatur dalam Undang-Undang Republik Indonesia Nomor 48 Tahun 2009 Tentang Kekuasaan Kehakiman.

Ada kecenderungan para hakim hingga saat ini demialasan aman dan kemudahan untuk menerapkan pasal-pasal dalam peraturan parundang-undangan terhadap peristiwa hukum, ia lebih cenderung untuk berfikir logis, mekanis linier dan sekedar membunyikan undangundang, ia lebih menitik beratkanpada kepastian hukumdibandingkan dengan rasa keadilan yang di inginkan masyarakat. Hakim dalam menjalankan tugasnya berpedoman pada Undang-Undang yang berlaku dan system, cara tersebut juga tidak dilarang, dalam arti jika hakim tidak mentaati akan dikenakansanksi atau hukuman, misalnya diturunkan pangkatnya atau di copot sebagai hakim.

Ada beberapa alasan yang memberi peluang agar hakim dapat berkreasi melakukan penemuan hukum atau menciptakan hukum yaitu: ${ }^{30}$

1. Hakim tidak terikat pada system

29 Koesnadi Harjasoemantri, 2017 Hukum Tata Lingkungan, Loc. Cit. hlm. 411

30 Dedy Muchti Nugroho, Penemuan Hukum Oleh Hakim dalam Perkara perdata Berdasar asas Peradilan yang Baik. Varia peradilan Tahun XXXIII No 388 Maret 21018, Jakarta Ikatan Hakim Indonesai (IKAHI) preseden;

2. Hakim wajib mengadili seluruh bagian gugatan;

3. Hakim tidak boleh menolak untuk memeriksa dan mengadili suatu kasus dengan alasan Undang-Undangnya tidak jelas atau tidak ada sama sekali.

Satjipto Rahardjo ${ }^{31}$ mengemukakan konsep hukum progresif yang mendasarkan asumsi "hukum adalah untuk manusia", memiliki tujuan besar berupa kesejahteraan dan kebahagian manusia, maka hukum selalu berada pada status law in the making. Paradigma hukum untukmanusia, member keleluasaan hakim bebas untuk mencari dan menemukan format, pikiran asas serta aksi-aksi yang tepat untuk mewujudkan nya, cara berhukum tersebut tidak hanya menggunakan rasio (logika), melainkan juga sarat dengan kenuranian atau compassion. Disinilah pintu masuk moralitas, yaitu empati, kejujuran, komitmen, dan keberanian.Bahwa hukum ada dalam undang-undang namun harus ditemukan, dengan demikian, kecerdasan moral seorang hakim melahirkan Judicial Discretion $^{32}$ dan mengubah mind set hakim legisme menjadi legaslistic and prismatic.

Menurut Roscoe Pound ${ }^{33}$ ada tiga langkah yang dilakukan hakim dalam mengadili suatu perkara:

1. Menemukan Hukum, menetapkan Kaidah dari sekian banyak kaidah didalam system hukum yang akan diterapkan, atau jika tidak ada yang dapat diterapkan (yang mungkin atau tidak mungkin dipakai sebagai salah satu kaidah untuk perkara lain sesudahmya) berdasarkan bahan yang sudah ada menurut uatu cara yang

31 Satjipto Raharjdo, Hukum Progresif Sebuah sistem hukum Indonesia Yogyakarta, genta Publishing, 2009, hlm. 47-48

32 Ronald Dworkin, 1978, Taking Rights Seriously, harvard University Press, Cambridge, Massachusette, hlm. 31

33 Roscoe Pound, A Intoductionto The Philosophy of Law, dierjemahkan oleh Mohammad Radjab, Pengantar Filsafat Hukum, Jakarta, Bhatara, 1998, hlm.62 
ditunjukkan oleh system hukum.

2. Menafsirkan kaidah yang dipilih atau ditetapkan, yaitu menentukan makna nya sebagaimana pada saat kaidah itu di bentuk;

3. Menerapkan pada perkara yang sedang dihadapi kaidah yang ditemukan dan ditafsirkan demikian.

Penemuan hukum oleh hakim di maksudkan bahwa hakim harus berani melakukan penafsiran untuk keluar dari makna teks Undang-Undang agar dapat berfungsi mewujudkan dan memberikan perlindungan bagi komunitas masyarakat pencari keadilan, Perundang-undangan Nasional berikut konkritisasinya dalam bentuk amar-amar putusan pengadilan dicitakan selalu terbuka terhadap berbagai kajian dan kritik dekonstruktif yang dilakukan lewat berbagai gerakan sosial peduli hukum, agar hukum nasional dapat berfungsi sebagai salah satu kekuatan penggalang kehidupan masyarakat Indonesia baru yang mampu bertindak responsive untuk kepentingan public. ${ }^{34}$

\section{Kesimpulan}

Kewajiban Hakim untuk menegak kan keadilan bersumber dari kewenangan nya yaitu kebijakan hakim/Judicial Discretion. Dengan demikian apabila hakim mengakabulkan ganti-rugi Materiel pada gugatan Perbutan Melanggar Hukum, sepanjang telah memenuhi Unsur-unsur Pasal 1365 KUHPerdata, yang membawa akibat hukum hakim dapat mengabulkan ganti-rugi Immateriel berdasarkan buktibukti yang ditemukan yang dapat dipertanggung-jawabkan.

Dikabulkannya gugatan ganti rugi Immateriel didasarkan pada Pertanggungjawaban hukum pelaku terhadap korban. Kewajiban Hakim untuk menegakkan keadilan bersumber dari kewenangannya

34 Soetantyo Wignjosoebroto, Pembahruan Hukum Masyarakat Indonesia Baru, Jakarta, Huma, 2007, hlm. 98 yaitu kebijakan hakim (Judicial Discretion), sebagai Moral principle The Foundation of Law.

\section{DAFTAR PUSTAKA}

Abdul Hakim Garuda Nusantara, 1988, PolitikHukum Indonesia, Jakarta: YLBHI, Jakarta

Abdulkadir Muhammad, 2000, Hukum Perdata Indonesia, Citra Aditya Bakti, Jakarta

Jaap C. Hage, 2010 .De Wereld van het Recht, dalam Recht, vaardig, en zeker, Een Inleiding in het recht, vijde druk, onder redactie van Jaap C. Hage,: Boom

Marc van Hoecke, 2002, Law as Communication, Oxford Portland Oregon: Hart Publishing,

Munir Fuady, 2013 Perbuatan Melawan Hukum Pendekatan Kontemporer, Citra Aditya Bakti, Bandung,

Mohtar Kusumaatmadja, 1995 Pemantapan Cita Hukum dan AsasAsas Hukum Nasional di Masa kini dan Masa yang akan Datang, seminar BPHN, Jakarata,

Nieuwenhuis, 1985, Pokok pokok Hukum Perikatan, diterjemahkan Djasadin siragih Surabaya Universitas Erlangga,

Peter Mahmud Marzuki, 2012 Pengantar Ilmu Hukum, Edisi Revisi, Kencana Prenada Media Group, Jakarta

Purwahid Patrik, 1994, Dasar-Dasar Hukum Prikatan, Mandar Maju Bandung

R. Subekti,1983Pokok-pokok Hukum Perdata, PT, Intermasa Jakarta

Ronald Dworkin, 1978Taking Right Seriously, The Belknap Press of Harvard University Press Cambridge, Massachusetts, London, England

Purwahid Patrik, 1994, Dasar-Dasar Hukum Prikatan, Mandar Maju Bandung.

Peter Mahmud Marzuki, 2011, An Introduction to Indonesian Law, 
Malang : Setara Press,

Purwoto Gondosubroto, 1984, Tugas Hakim Indonesia. Dalam selo sumarjan et.al eds.Guru Pinandito Sumbangsih Untuk prof, Djokosoeono, SH. Lembaga penerbit FE UI. Jakarta

Rudy Prasetyo, 1982. Kedudukan Mandiri Dan Pertanggung-jawaban Terbatas Dari Perseroan Terbatas, Diss. Universitas Erlangga, Dalil

Rosa Agustina, 2012, Hukum Perikatan, Law Of Obligation, Pustaka Larasan, Denpasar

R. Setiawan, 1979,Pokok-pokok Hukum Perikatan, Bandung : Binacipta, Satjipto Rahardjo, Pengantar Ilmu Hukum

Shidarta, Hukum Penalaran dan Penalaran Hukum, Genta Publishing, Jakarat, 2013.

Soerjono Soekanto, 2005, Pokok-Pokok Sosiologi Hukum, Jakarta: PT. Raja
Grafindo Persada,

Sudikno Mertokusumo, 2003 Mengenal Hukum Suatu Pengantar, Liberty, Yogyakarta 2000 Penemuan Hukum, Edisi kedua. Cetakan Pertama, liberty, Yogyakarta.

Soediman Kartohardiprodjo, 1987 Pengantar Hukum Indonesia 1 Hukum Perdata, Cet-11, Jakarta : Ghalia Indonesia,

Soetandyo Widjosoebroto, .2002. Penelitian hukum doctrinal dalam Hukum Paradigma, Metode dan Dinamaki masalahnya, Huma Jakarta

Titik Triwulan Tutik, 2014. Hukum Perdata Dalam System Hukum Nasional, cet-4, Kencana Prenadamedia Jakarta: 